\title{
Effect of simulated rainfall during wheat seed development and maturation on subsequent seed longevity is reversible
}

\author{
Richard H. Ellis ${ }^{\star}$ and Gajender Yadav ${ }^{\dagger}$ \\ School of Agriculture, Policy and Development, University of Reading, Earley Gate, PO Box 237, \\ Reading RG6 6AR, UK
}

(Received 26 August 2015; accepted after revision 4 December 2015; first published online 8 January 2016)

\begin{abstract}
Poor wheat seed quality in temperate regions is often ascribed to wet production environments. We investigated the possible effect of simulated rain during seed development and maturation on seed longevity in wheat (Triticum aestivum L.) cv. Tybalt grown in the field $(2008,2009)$ or a polythene tunnel house (2010). To mimic rain, the seed crops were wetted from above with the equivalent of $30 \mathrm{~mm}(2008,2009)$ or $25 \mathrm{~mm}$ rainfall (2010) at different stages of seed development and maturation (17-58 DAA, days after 50\% anthesis), samples were harvested serially, and subsequent air-dry seed longevity estimated. No pre-harvest sprouting occurred. Seed longevity ( $p_{50}, 50 \%$ survival period in experimental hermetic storage at $40^{\circ} \mathrm{C}$ with c. $15 \%$ moisture content) in field-grown controls increased during seed development and maturation, attaining maxima at 37 (2008) or 44 DAA (2009); it declined thereafter. Immediate effects of simulated rain at 17-58 DAA in field studies $(2008,2009)$ on subsequent seed longevity were negative but small, e.g. a 1-4d delay in seed quality improvement for treatments early in development, but with no damage detected at final harvests. In rainfall-protected conditions (2010), simulated rain close to harvest maturity (55-56 DAA) reduced longevity immediately and substantially, with greater damage from two sequential days of wetting than one; again, later harvests provided evidence of recovery in subsequent longevity. In the absence of pre-harvest sprouting, the potentially deleterious effects of rainfall to wheat seed crops on subsequent seed longevity may be reversible in full or in part.
\end{abstract}

\footnotetext{
*Correspondence

Email: r.h.ellis@reading.ac.uk

${ }^{\dagger}$ Present address: Division of Soil and Crop Management, ICAR-Central Soil Salinity Research Institute, Zarifa Farm, Kachhwa Road, Karnal-132001, India.
}

Keywords: development, germination, Iongevity, rain, Triticum aestivum L., viability, wheat

\section{Introduction}

Rainfall is important to cereal crop production, since drought can reduce grain yield and quality (Gooding et al., 2003; Sivakumar et al., 2005). In general, rainfall during vegetative growth promotes high yield, but heavy rainfall during seed development and maturation provides poor seed quality (Thomson, 1979; Tu et al., 1988; Olivares et al., 2009).

Wet summers in cool temperate environments are generally associated with poor wheat (Triticum aestivum L.) quality, whether for establishing subsequent crops (MacKay, 1972) or for bread-making purposes (Smith and Gooding, 1999). Indeed, an association between the North Atlantic Oscillation, wet cool UK summers, and poor wheat seed quality has been noted (Kettlewell et al., 2003) - including reduced specific weight through alternate wetting and drying cycles causing grain wrinkling. Moreover, rainfall before harvest may make harvesting conditions difficult (Landau et al., 2000).

Under very wet and cool production environments, maturing wheat seed can show gross evidence of damage from rainfall due to viviparous germination, usually with readily visible pre-harvest sprouting (Mitchell et al., 1980; King, 1993; Thomason et al., 2009). During seed development and maturation, wheat seed quality, as assessed by subsequent air-dry seed survival period (i.e. longevity), has been shown to improve progressively, reaching maximum values some 2-3 weeks after mass maturity (end of the seed-filling period) (Ellis and Pieta-Filho, 1992; Sanhewe et al., 1996). Similar conclusions have been drawn in other cereals (Pieta-Filho and Ellis, 1991; Rao et al., 1991; Ellis et al., 1993). These studies have shown subsequent seed longevity to be a more sensitive measure of seed quality than ability to germinate. 
Anthropogenic greenhouse gas emissions, including carbon dioxide, continue to rise and climates later this century will be warmer with more intense and more frequent extreme precipitation events (Intergovernmental Panel on Climate Change, 2014). Sanhewe et al. (1996) showed a progressive, positive effect of temperature (within the range investigated) on the development of subsequent wheat seed longevity, but no effect of carbon dioxide concentration. Here, we applied simulated rain to wheat crops at different stages of seed development and maturation to test the null hypotheses of no effect of rainfall on subsequent seed longevity and no interaction with developmental stage. The literature on extreme rainfall events is clear-cut, particularly where damage in the field prevents harvest, where for example pregermination in barley (Hordeum vulgare L.) is known to reduce subsequent longevity (Gualano et al., 2014). This study focused on less extreme treatments which did not result in pre-harvest sprouting, initially in the field and later in a protected environment, given that if germination does not occur, then wetting treatments to mature seeds (i.e. after harvest) can be of benefit to seed survival (Villiers and Edgecumbe, 1975).

\section{Materials and methods}

Wheat (Triticum aestivum L.) cv. Tybalt (suitable for autumn or spring sowing) was grown in the field at the Crop Research Unit, Sonning, UK (51 $\left.30^{\prime} \mathrm{N}, 00^{\circ} 54^{\prime} \mathrm{W}\right)$ in each of 2007-2008 and 2009, with standard agronomy (muriate of potash applied at $90 \mathrm{~kg} \mathrm{~K}_{2} \mathrm{Oha}^{-1}$ in autumn before sowing; ammonium nitrate applied to crops in spring at $100 \mathrm{~kg} \mathrm{Nha}^{-1}$ ), or in pots in a polythene tunnel house at the Plant Environment Laboratory, Shinfield, UK in $2010\left(51^{\circ} 27^{\prime} \mathrm{N}, 00^{\circ} 56^{\prime} \mathrm{W}\right)$.

\section{8}

Seeds were sown $4 \mathrm{~cm}$ deep at 300 seeds per $\mathrm{m}^{2}$ in rows $12 \mathrm{~cm}$ apart on 31 October 2007 in plots $1.9 \mathrm{~m}$ wide, $5 \mathrm{~m}$ long and $0.6 \mathrm{~m}$ apart. Two blocks (A and B) were used in the field investigations to provide replication; results are presented separately for each block to provide information on the repeatability of any responses detected. Each block comprised three plots: control, natural rain only; wetting 1 , simulated rain applied on 8 July 2008 [17 DAA (days after 50\% anthesis)]; wetting 2, 23 July (32 DAA). Rainfall was simulated by applying the equivalent of $30 \mathrm{~mm}$ from above with a watering can with rose attached: half was applied first; then, after a 30-min delay, the remainder. Wettings were made at $08.00-10.00 \mathrm{~h}$ to allow time for subsequent harvests and laboratory work.
In the control, the first harvest was on 2 July 2008 (11 DAA). Subsequent harvests (2-6) were at 17, 23, 30, 37 and 51 DAA (11 August). In wetting 1, the first harvest was on 8 July 2008 (17 DAA) immediately before wetting, and the second $3 \mathrm{~h}$ after wetting (nominally 17.13 DAA) with harvests 3-7 at 20, 23, 30, 37 and 51 DAA. For wetting 2, the first harvest was on 23 July 2008 (32 DAA) immediately before wetting, and the second $3 \mathrm{~h}$ after (nominally $32.13 \mathrm{DAA}$ ) with harvests $3-6$ at 34, 37, 39 and 51 DAA.

\section{9}

Seeds were sown $4 \mathrm{~cm}$ deep at 400 seeds per $\mathrm{m}^{2}$ on 16 March 2009 in two blocks (other details as above), with four treatments: control, natural rain only; wetting 1, simulated rain on 13 July 2009 (29 DAA); wetting 2 , simulated rain on 28 July (44 DAA); wetting 3 , simulated rain on 11 August (58 DAA).

In the control, the first harvest was on 29 June (15 DAA). Subsequent harvests $2-7$ were at 22, 29, 36, 44, 57 and 68 DAA (21 August), respectively. For wetting 1 , the first harvest was on 13 July (29 DAA), the second $2 \mathrm{~h}$ after wetting (nominally 29.08 DAA), with harvests $3-7$ at 31, 36, 44, 57 and 68 DAA. For wetting 2 , the first harvest was on 27 July (43 DAA) immediately before wetting, and later ones (2-5) $2 \mathrm{~h}$ after wetting (nominally 43.08 DAA), 46, 57 and 68 DAA. For wetting 3, harvests 1-4 were from 11 August (58 DAA) immediately before wetting, $2 \mathrm{~h}$ after wetting (nominally 58.08 DAA), 60 and 68 DAA.

\section{0}

Seeds were sown $2 \mathrm{~cm}$ deep in pots $(18 \mathrm{~cm}$ diameter, 3 litre volume) at the equivalent of 215 seeds $\mathrm{m}^{-2}$ on 14 April 2010. The pots were adjacent to each other in the middle of a well-ventilated polythene tunnel house $(31 \times 8 \mathrm{~m})$, i.e. not subject to rain and only slightly warmer than ambient (fan-assisted ventilation was provided to reduce solar gain). The growing medium comprised sterilized vermiculite, sand, gravel and compost in the ratio of 4:2:4:1, mixed with Osmocote (Osmocote Exact-Scotts, Everris International B.V., Geldermalsen, The Netherlands) slow-release granules $\left(2 \mathrm{~kg} \mathrm{~m}^{-3}\right)\left(\mathrm{N}: \mathrm{P}_{2} \mathrm{O}_{5}: \mathrm{K}_{2} \mathrm{O}: \mathrm{MgO} ; 15: 11: 13: 2\right)$. Pots were irrigated through an automated drip-feed system; once a day initially, later twice a day. The rainfall simulation was the equivalent of $25 \mathrm{~mm}$ rainfall, with two treatments applied late in seed maturation. Control plants were harvested at 55 (10 August), 56 (11 August) or 62 DAA (17 August). Wetting 1 was at 56 DAA, with seeds harvested $30 \mathrm{~min}$ after wetting (nominally 56.02 DAA) and $6 \mathrm{~d}$ later (62 DAA). The second treatment comprised two simulated rainfall events $1 \mathrm{~d}$ apart, each of $25 \mathrm{~mm}$, 
at 55 and 56 DAA. The first harvest was 30 min after the first wetting (nominally 55.02 DAA), the second just before (nominally $55.98 \mathrm{DAA}$ ) and the third $30 \mathrm{~min}$ after (nominally 56.02 DAA) the second wetting, with a final harvest at 62 DAA.

\section{Seed harvest}

Each harvest comprised 60-80 ears from an area of $<0.5 \mathrm{~m}^{2}$ selected at random within each plot. Samples were then taken to the laboratory and seeds threshed out by hand; 100 seeds plus $1 \mathrm{~g}$ were withdrawn from each sample to estimate ability to germinate, seed moisture content and seed weight. The remaining seeds were dried to $10-14 \%$ moisture content (wet basis) in a drying cabinet $\left(15-17^{\circ} \mathrm{C}\right.$ with $12-15 \%$ relative humidity), and each sample stored hermetically at $-20^{\circ} \mathrm{C}$ until the determination of longevity.

\section{Seed moisture content}

Seed moisture contents were determined using the high-constant-temperature-oven method (International Seed Testing Association, 2011), the only variation being that $2 \times 100$ seed samples were used in place of $2 \times 4-5 \mathrm{~g}$ samples. The two-stage method (International Seed Testing Association, 2011) was used for moist seeds.

\section{Ability to germinate}

Freshly harvested seeds and dried seeds $(<15 \%$ moisture content) were tested for ability to germinate between moist, rolled paper towels (Kimberley Clark Professional 6803 HOSTESS, Natural, $24 \times 35 \mathrm{~cm}$, Greenham Sales, UK) in an incubator at $10^{\circ} \mathrm{C}$ for $28 \mathrm{~d}$, initially. Seeds remaining ungerminated and fresh were then pricked and returned to the test until all seeds had either germinated or rotted. Radicle emergence was the criterion of germination.

\section{Seed longevity in hermetic storage}

Seeds withdrawn from $-20^{\circ} \mathrm{C}$ were kept sealed overnight at $20^{\circ} \mathrm{C}$ to warm before opening the packets. The moisture content of each sample was adjusted (to $15 \pm 0.2 \%$ ) by humidification above water at $20^{\circ} \mathrm{C}$ (for $2-24 \mathrm{~h}$, depending on initial moisture content), then stored hermetically at $3-5^{\circ} \mathrm{C}$ for $5 \mathrm{~d}$, and a sample was withdrawn for moisture content determination. For each seed lot, 9-10 samples of 100 seeds (depending upon total sample size) were sealed in separate laminated-aluminium-foil bags (Retort laminate, Moore and Buckle Ltd, St Helens, UK). These bags were then stored in an incubator maintained at $40^{\circ} \mathrm{C}\left( \pm 0.5^{\circ} \mathrm{C}\right)$. Samples were removed from experimental storage to test ability to germinate (as above) at regular intervals for up to 34 (2008 and 2009) or $42 \mathrm{~d}$ (2010). Seed survival curves were fitted to the observations by probit analysis using Genstat (13th edition, VSN International Ltd., Hemel Hempstead, UK), in which analyses the criterion of survival was the ability of a seed to produce a normal seedling (International Seed Testing Association, 2011), providing estimates of $\sigma, K_{i}$ and $p_{50}$ in accordance with the seed viability equation (Ellis and Roberts, 1980):

$$
v=K_{i}-p / \sigma
$$

where $v$ is probit percentage viability after $p$ days in storage, $\sigma$ is the standard deviation of the frequency distribution of seed deaths in time (d), $K_{i}$ is a constant (theoretical probit percentage viability at start of experimental storage) and $p_{50}$ (the product of $K_{i}$ and $\sigma$ ) is the period (d) in storage for viability to decline to $50 \%$.

\section{Results}

Average mean temperature and total rainfall during seed development and maturation in the field were $16.7^{\circ} \mathrm{C}$ and $107.8 \mathrm{~mm}$ (anthesis to last harvest, 1 July to 11 August 2008); and $16.8^{\circ} \mathrm{C}$ and $92.6 \mathrm{~mm}$ (25 June to 21 August 2009). Hence, mean temperatures were similar amongst years and developing seeds received only $15.2 \mathrm{~mm}$ more rain in 2008 than 2009 . Heavy rains $\left(>10 \mathrm{~mm} \mathrm{~d}^{-1}\right.$, total $\left.64 \mathrm{~mm}\right)$ occurred during the 3 weeks after anthesis in 2008, coinciding with the first treatment, while heavy rain $(17 \mathrm{~mm})$ occurred $3 \mathrm{~d}$ before the third wetting in 2009 (Fig. 1). The crops were observed to reach $50 \%$ anthesis on 21 June 2008 and 14 June 2009, with the end of the seed-filling period, mass maturity, at about 21 DAA (2008) and 25 DAA (2009). In the polythene tunnel house, the mean temperature from $50 \%$ anthesis (16 June 2010) to the last harvest was $19.7^{\circ} \mathrm{C}$, with extremes of 28.5 and $9.4^{\circ} \mathrm{C}$. While the summer ambient temperature in 2010 was marginally warmer than either 2008 or 2009, the higher mean temperature in 2010 given above largely reflects the effect of the protected environment.

\section{Seed moisture content}

In the two field-crop studies, seed moisture content in the control declined more slowly in the 6 or so weeks after anthesis in 2008 than in 2009 - from 59\% at 11 DAA to about $24 \%$ at 37 DAA in 2008 (Fig. 1a, c), and from $67 \%$ at 15 DAA to about $22 \%$ at 44 DAA in 2009 (Fig. 1b, d) - in accordance with differences in rainfall over this period between years (Fig. 1e, f). 


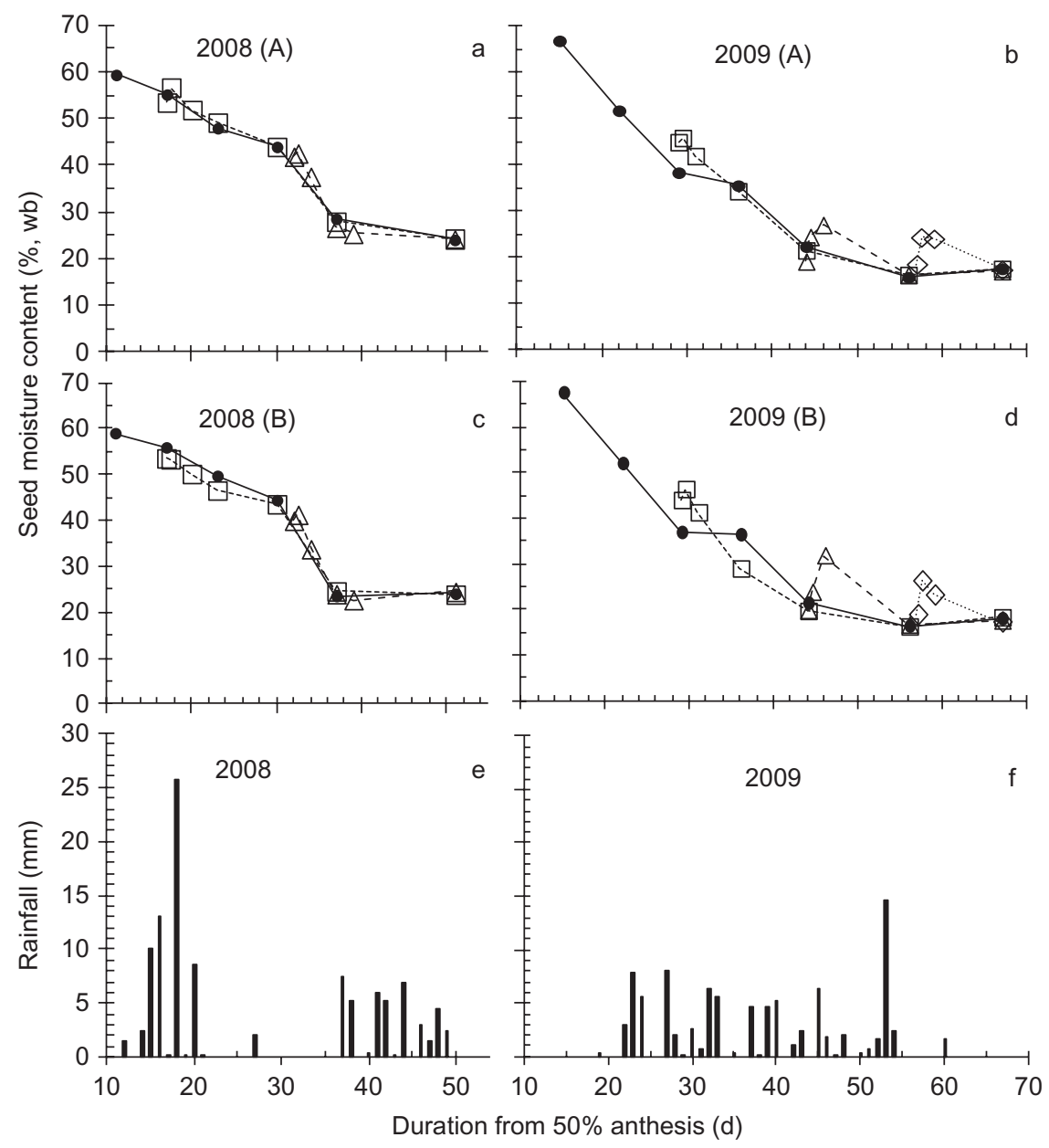

Figure 1. Effect of simulated rainfall (30 mm applied above the canopy) on the moisture content [\%, wet basis (wb)] of wheat seeds harvested serially during development and maturation of field-grown crops for control (-0-, no simulated additional rainfall), wetting $1(\cdots \square \cdot . \cdot)$, wetting $2(--\triangle--)$ or wetting $3(\bullet)$ treatments in $2008(a, c)$ or $2009(b, d)$ in Blocks A (a, b) and B (c, d), and the rainfall $(\mathrm{mm})$ received each day during the experimental periods $(\mathrm{e}, \mathrm{f})$.

In 2008, the two simulated rainfall treatments had no detectable effect $(P>0.25)$ on seed moisture content (Fig. 1a, c), whereas in 2009 all three treatments increased $(P<0.05)$ seed moisture content by some 6-10\% temporarily, with control values regained some 5-10 d later (Fig. 1b, d). In 2010, seed moisture content of the control, at and after harvest maturity, was stable at $14.1-14.5 \%$ during the experimental period (Fig. 2). Immediately after simulated rainfall, seed moisture content increased $(P<0.05)$ by $4.3-5.0 \%$, but reverted to control values as soon as $24 \mathrm{~h}$ later (Fig. 2).

\section{Seed viability and longevity}

No pre-harvest sprouting occurred in the controls or treatments in any year. With dormancy overcome by testing at $10^{\circ} \mathrm{C}$ combined with pricking, the majority of seeds were able to germinate from the earliest harvests (e.g. $91 \%$ at early as 11 DAA in 2008), such that all samples from 23 DAA until the last harvests for all treatments showed $100 \%$, or close to, viability (data not shown).

Within each of the 3 years, seed survival curves varied substantially (Table 1) amongst treatment combinations: $K_{i}$ varied significantly with wetting treatment $(P<0.001$ for 2008, 2009 and 2010), harvest date $(P<0.001, P<0.01, P<0.001$ for 2008, 2009 and 2010, respectively) and harvest date $\times$ treatment $(P<0.05, P<0.001$ for 2008 and 2009, respectively); and $1 / \sigma$ varied significantly with wetting treatment $(P<0.05, P<0.005, P<0.001$ for 2008, 2009 and 2010, respectively), harvest date $(P<0.001$, $P<0.01, P<0.001$ for 2008, 2009 and 2010, respectively) and harvest date $\times$ treatment $(P<0.001$ for 2008 and 2009). There was a 3.5 -fold maximum variation in longevity ( $p_{50}$ ) within 2008, 4.1-fold in 2009, and 2.7-fold in 2010, with differences in both $K_{i}$ and $\sigma$ (Table 1). The major driver of this variation in the 2008 and 2009 field investigations was the period of seed development and 


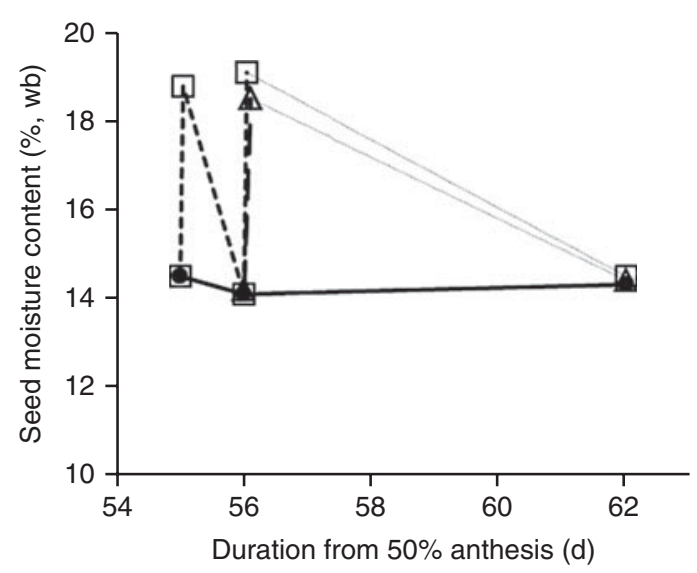

Figure 2. Effect of simulated rainfall $(25 \mathrm{~mm}$ applied above the canopy) on the moisture content $(\%, w b)$ of wheat seeds from serial harvests at or after harvest maturity produced protected from rainfall in a polythene tunnel house for control (--, no simulated rainfall), wetting once at 56 DAA $(\triangle)$ or wetting on two consecutive days $(-\boxminus)$ at 55 and 56 DAA. The dotted lines joining symbols between 56 and 62 DAA do not represent the probable negative exponential pattern of drying.

maturation (Fig. 3). In contrast, in 2010, where samples were only harvested after the end of maturation drying, the variation in longevity resulted from wetting treatments (Fig. 4).

In both 2008 and 2009, clear and consistent (across both blocks and treatments) patterns of the effect of developmental period on longevity were detected, with increase in longevity until 37-39 DAA (2008) or 44-46 DAA (2009) with a subsequent decline in longevity thereafter (Fig. 3). There was a single outlier to the above: Block B wetting 1 in 2009, where peak longevity occurred earlier, at 36 DAA (Fig. 3d).

In 2008, wetting 1 at 17 DAA (about $4 \mathrm{~d}$ before mass maturity, when seed moisture content was about $55-56 \%$ ) led to an almost consistent but small reduction in longevity compared with the control in the period 17-30 DAA (Fig. 3a, c). This was equivalent to a 2- to 4-d delay in the developmental pattern of improvement in longevity. From 37 DAA onwards, however, longevity was no less than the control and often slightly greater. Wetting 2 at 32 DAA (about $11 \mathrm{~d}$ after mass maturity, when seed moisture content was close to $40 \%$ ), also led to slightly shorter longevity than the control over the subsequent 2 (Block A, Fig. 3a) to $5 \mathrm{~d}$ (Block B, Fig. 3c), equivalent to about a 4-d delay in the developmental pattern of improvement in longevity, but thereafter longevity was similar to, or slightly greater than, the control.

In 2009, wetting 1 at 29 DAA ( $4 \mathrm{~d}$ after mass maturity, when seed moisture content had declined to $37-38 \%$ ) resulted in some fluctuation in longevity (a brief reduction on the day of wetting), but throughout subsequent maturation drying longevity was no less than the control (Fig. 3b, d). Wetting 2 at 43 DAA (18 d after mass maturity, when moisture content had declined to $21-23 \%$ ) similarly provided a brief reduction in longevity, but with later harvests identical to the control. Wetting 3 applied at 58 DAA (33 d after mass maturity, when moisture content had declined to about $16 \%$ ) similarly led to a brief reduction in longevity, but with later harvests identical to the control.

The longevity of the control in the protected environment of 2010 varied only from $39 \mathrm{~d}$ at 55 DAA to $37 \mathrm{~d}$ at 62 DAA, but all three wetting treatments reduced longevity immediately $(P<0.05)$ and substantially (Fig. 4). Subsequently, however, longevity improved to (first wetting at 55 DAA, $P>0.10$ ), or towards (remaining treatments at 62 DAA, $P<0.05)$, control values. Single wettings were less damaging to longevity than wetting on two consecutive days $(P<0.05)$.

\section{Discussion}

The pattern of increase in subsequent air-dry longevity during seed development and maturation in the field to maxima at around 16 (2008) to $21 \mathrm{~d}$ (2009) after mass maturity is in accordance with earlier studies in wheat (Ellis and Pieta-Filho, 1992; Sanhewe et al., 1996). There was good agreement between the 2 years of field experiments for estimates of peak longevity in the controls $\left(p_{50}=17-23 \mathrm{~d}\right.$, Fig. 3), which received considerable rainfall (Fig. 1e, f), whereas the 2010 controls protected from rainfall in the polythene tunnel house provided substantially greater estimates $\left(p_{50}=37-39 \mathrm{~d}\right.$, Fig. 4). This investigation was not designed to enable comparisons amongst years but, while a benefit from protection from rainfall throughout seed development and maturation in 2010 cannot be ruled out, it seems probable from Sanhewe et al. (1996) that the $3^{\circ} \mathrm{C}$ warmer environment is the more likely (though not necessarily exclusive) explanation.

Provided seed germination can be prevented, airdry seed storage survival may, on occasion, benefit from wetting-drying cycles: for example, repeated imbibition-drying cycles to mature seed ex planta aided lettuce (Lactuca sativa L.) seed long-term survival (Villiers and Edgecumbe, 1975); and the air-dry longevity of foxglove (Digitalis purpurea L.) seeds harvested close to maturity could be increased by immediate priming and dehydration (Butler et al., 2009). The topic is controversial, however, since many studies of seed priming and other forms of rehydration have been shown to damage longevity (e.g. Argerich et al., 1989; Tarquis and Bradford, 1992) and desiccation tolerance (Hong and Ellis, 1992).

Both wetting treatments to developing wheat seeds in 2008 were before peak longevity was detected. 
Table 1. Estimates of the seed lot constant $\left(K_{i}\right)$, slope $(1 / \sigma)$ and longevity $\left(p_{50}, \mathrm{~d}\right)$ for seed survival curves of wheat cv. Tybalt produced in 2008, 2009 and 2010 under different wetting regimes harvested at different times during seed development and maturation. Seed survival curves were fitted by probit analysis in accordance with the seed viability equation (Ellis and Roberts, 1980)

\begin{tabular}{|c|c|c|c|c|c|c|c|}
\hline \multirow[b]{2}{*}{ Sample } & \multirow[b]{2}{*}{ DAA } & \multicolumn{3}{|c|}{ Block A } & \multicolumn{3}{|c|}{ Block B } \\
\hline & & $K_{i}$ & Slope $(1 / \sigma)$ & $p_{50}(\mathrm{~d})$ & $K_{i}$ & Slope $(1 / \sigma)$ & $p_{50}(\mathrm{~d})$ \\
\hline \multicolumn{8}{|l|}{2008 - Control } \\
\hline Harvest 1 & 11 & $1.21(0.098)$ & $0.166(0.0104)$ & $7.3(0.33)$ & $1.59(0.113)$ & $0.120(0.0121)$ & $8.0(0.29)$ \\
\hline Harvest 2 & 17 & $2.51(0.172)$ & $0.275(0.0180)$ & $9.1(0.24)$ & $2.14(0.159)$ & $0.265(0.0188)$ & $8.1(0.25)$ \\
\hline Harvest 3 & 23 & $3.51(0.238)$ & $0.326(0.0222)$ & $10.8(0.23)$ & $3.01(0.191)$ & $0.270(0.0169)$ & $11.2(0.25)$ \\
\hline Harvest 4 & 30 & $3.21(0.212)$ & $0.277(0.0185)$ & $11.6(0.26)$ & $3.12(0.189)$ & $0.237(0.0143)$ & $13.2(0.28)$ \\
\hline Harvest 5 & 37 & $3.78(0.237)$ & $0.179(0.0121)$ & $21.2(0.43)$ & $5.09(0.336)$ & $0.221(0.0150)$ & $23.0(0.38)$ \\
\hline Harvest 6 & 51 & $3.83(0.244)$ & $0.283(0.0180)$ & $13.5(0.26)$ & $3.57(0.222)$ & $0.229(0.0146)$ & $15.6(0.30)$ \\
\hline \multicolumn{8}{|l|}{2008 - Wetting 1} \\
\hline Harvest 1 (before wetting) & 17 & $2.32(0.154)$ & $0.276(0.0171)$ & $8.4(0.25)$ & $2.08(0.153)$ & $0.284(0.0188)$ & $7.3(0.24))$ \\
\hline Harvest 2 ( $3 \mathrm{~h}$ after $)$ & 17.13 & $2.07(0.134)$ & $0.237(0.0143)$ & $8.8(0.27)$ & $1.97(0.128)$ & $0.213(0.0127)$ & $9.2(0.29)$ \\
\hline Harvest 3 & 20 & $2.34(0.151)$ & $0.249(0.0153)$ & $9.4(0.27)$ & $2.70(0.190)$ & $0.299(0.0204)$ & $9.0(0.23)$ \\
\hline Harvest 4 & 23 & $3.61(0.269)$ & $0.353(0.0258)$ & $10.2(0.23)$ & $3.86(0.280)$ & $0.385(0.0283)$ & $10.0(0.21)$ \\
\hline Harvest 5 & 30 & $4.06(0.300)$ & $0.363(0.0264)$ & $11.2(0.23)$ & $4.36(0.290)$ & $0.366(0.0245)$ & $11.9(0.22)$ \\
\hline Harvest 6 & 37 & $4.60(0.292)$ & $0.203(0.0133)$ & $22.7(0.39)$ & $3.47(0.219)$ & $0.136(0.0097)$ & $25.6(0.54)$ \\
\hline Harvest 7 & 51 & $3.44(0.220)$ & $0.229(0.0148)$ & $15.0(0.30)$ & $3.44(0.208)$ & $0.223(0.0137)$ & $15.4(0.30)$ \\
\hline \multicolumn{8}{|l|}{2008 - Wetting 2} \\
\hline Harvest 1 (before we & 32 & $3.68(0.245)$ & $0.266(0.0175)$ & $13.8(0.27)$ & $4.38(0.291)$ & $0.359(0.0239)$ & $12.2(0.23)$ \\
\hline Harvest 2 (3 h after) & 32.13 & $2.74(0.165)$ & $0.209(0.0124)$ & $13.1(0.31)$ & $3.18(0.195)$ & $0.244(0.0$ & 13.0 \\
\hline Harvest 3 & 34 & $3.54(0.230)$ & $0.245(0.0159)$ & $14.5(0.29)$ & $4.93(0.361)$ & $0.300(0.0222)$ & 16.4 \\
\hline Harvest 4 & 37 & $4.13(0.254)$ & $0.194(0.0124)$ & $21.3(0.39)$ & $4.54(0.295)$ & $0.218(0.0149)$ & $20.8(0.37)$ \\
\hline Harvest 5 & 39 & $4.71(0.299)$ & $0.120(0.0130)$ & $23.6(0.40)$ & $3.57(0.201)$ & $0.168(0.0099)$ & $21.3(0.42)$ \\
\hline Harvest 6 & 51 & $3.43(0.193)$ & $0.162(0.0095)$ & $21.2(0.42)$ & $4.04(0.262)$ & $0.224(0.0152)$ & $18.0(0.33)$ \\
\hline \multicolumn{8}{|l|}{2009 - Control } \\
\hline Harvest 1 & 15 & $0.41(0.086)$ & 0.09 & $4.1(0.67)$ & $0.71(0.086)$ & 0.11 & $5.9(0.46)$ \\
\hline Harv & 22 & $2.12(0.130)$ & $0.211(0.0121)$ & $10.0(0.29)$ & $1.90(0.127)$ & $0.217(0.0131)$ & $8.7(0.27)$ \\
\hline Harvest 3 & 29 & $6.62(0.600)$ & $0.618(0.0586)$ & 10.7 (0.19) & $6.31(0.510)$ & $0.580(0.0490)$ & $10.9(0.19)$ \\
\hline Harvest 4 & 36 & $8.34(0.922)$ & 0.777 (0.0918) & 10.7 (0.19) & $8.14(0.960)$ & $0.784(0.0984)$ & $10.4(0.18)$ \\
\hline Harvest 5 & 44 & $6.18(0.513)$ & $0.375(0.0312)$ & $16.5(0.24)$ & $6.81(0.584)$ & $0.379(0.0329)$ & $18.0(0.24)$ \\
\hline Harvest 6 & 57 & $9.41(1.000)$ & $0.614(0.0647)$ & $15.3(0.18)$ & $6.66(0.595)$ & $0.436(0.0385)$ & $15.3(0.21)$ \\
\hline Harvest 7 & 68 & $7.23(0.587)$ & $0.603(0.0487)$ & $12.0(0.19)$ & $5.71(0.419)$ & $0.448(0.0325)$ & $12.8(0.21)$ \\
\hline \multicolumn{8}{|l|}{2009 - Wetting 1} \\
\hline Harvest 1 (before wetting) & 29 & $5.87(0450)$ & 0.459 & 12.8 & $6.71(0.553)$ & 0.508( & $0.20)$ \\
\hline Harvest 2 (2 h after) & 29.08 & $6.34(0.498)$ & $0.547(0.0435)$ & $11.6(0.19)$ & $7.62(0.635)$ & $0.670(0.0$ & $11.4(0.19)$ \\
\hline Harvest 3 & 31 & $7.44(0.915)$ & $0.745(0.0959)$ & $10.0(0.17)$ & $7.20(0.577)$ & $0.625(0.0513)$ & $11.5(0.19)$ \\
\hline Harvest 4 & 36 & $9.06(1.000)$ & $0.688(0.0733)$ & $13.2(0.19)$ & $6.41(0.620)$ & $0.326(0.0333)$ & $19.7(0.31)$ \\
\hline Harvest 5 & 44 & $7.80(0.677)$ & $0.440(0.0385)$ & $17.8(0.22)$ & $10.68(0.972)$ & $0.564(0.0$ & $18.9(0.23)$ \\
\hline Harvest 6 & 57 & $7.67(0.766)$ & $0.513(0.0504)$ & $15.0(0.20)$ & $10.12(1.090)$ & $0.675(0.0719)$ & $15.0(0.17)$ \\
\hline Harvest 7 & 68 & $5.75(0.446)$ & $0.432(0.0328)$ & $13.3(0.21)$ & $5.77(0.427)$ & $0.448(0.0328)$ & $12.9(0.21)$ \\
\hline \multicolumn{8}{|l|}{2009 - Wetting 2} \\
\hline Harvest 1 (before & 43 & $10.26(0.950)$ & $0.537(0.0$ & 19.1 & 6) & 0.43 & 16.8 \\
\hline Harvest 2 ( $2 \mathrm{~h}$ after) & 43.08 & $6.28(0.538)$ & $0.419(0.0354)$ & 15.0 & 3) & $0.390(0$. & $15.8(0.23)$ \\
\hline Harvest 3 & 46 & $3.79(0.246)$ & $0.211(0.0143)$ & $18.0(0.35)$ & $5.91(0.465)$ & $0.381(0.0302)$ & $15.2(0.23)$ \\
\hline Harvest 4 & 57 & $7.60(0.753)$ & $0.516(0.0501)$ & $14.8(0.20)$ & $5.05(0.365)$ & $0.343(0.0246)$ & $14.7(0.24)$ \\
\hline Harvest 5 & 68 & $6.56(0.532)$ & $0.507(0.0402)$ & $12.9(0.20)$ & $7.55(0.739)$ & $0.486(0.0473)$ & $15.5(0.20)$ \\
\hline \multicolumn{8}{|l|}{2009 - Wetting 3} \\
\hline Harvest 1 (before & 58 & $6.32(0.500)$ & $0.491(0.0$ & 12.9 & 0.04 (0. & 0.38 & 14.4 \\
\hline Harvest 2 ( $2 \mathrm{~h}$ after $)$ & 58.08 & $4.94(0.365)$ & $0.329(0.0241)$ & $15.0(0$. & $6.60(0.6$ & $0.437(0.0434)$ & $15.1(0.22)$ \\
\hline Harvest 3 & 60 & $5.42(0.405)$ & $0.433(0.0319)$ & $12.5(0.21)$ & $5.07(0.359)$ & $0.376(0.0263)$ & $13.5(0.23)$ \\
\hline Harvest 4 & 68 & $6.095(0.468)$ & $0.504(0.0386)$ & $12.1(0.20)$ & $6.68(0.544)$ & $0.511(0.0408)$ & $13.1(0.20)$ \\
\hline 2010 & & & ouble wetting & & & Single wetting & \\
\hline Control 1 & 55 & $11.870(1.200)$ & $0.304(0.0308)$ & $39.1(0.38)$ & & & \\
\hline Control 2 & 56 & $10.650(1.030)$ & $0.282(0.0274)$ & $37.8(0.39)$ & & & \\
\hline Control 3 & 62 & $7.676(0.653)$ & $0.206(0.0178)$ & $37.3(0.46)$ & & & \\
\hline Harvest 1 (30 min after) & 55.02 & $4.555(0.284)$ & $0.170(0.0110)$ & $26.8(0.41)$ & & & \\
\hline Harvest 2 (before wetting 2) & 56 & $10.010(0.953)$ & $0.268(0.0254)$ & $37.4(0.40)$ & & & \\
\hline Harvest 3 (30 min after) & 56.02 & $4.489(0.437)$ & $0.310(0.0276)$ & $14.5(0.30)$ & $4.57(0.320)$ & $0.211(0.0147)$ & $21.6(0.32)$ \\
\hline Harvest 4 & 62 & $15.640(1.570)$ & $0.485(0.0473)$ & $32.2(0.33)$ & $8.64(0.714)$ & $0.247(0.0205)$ & $35.0(0.40)$ \\
\hline
\end{tabular}




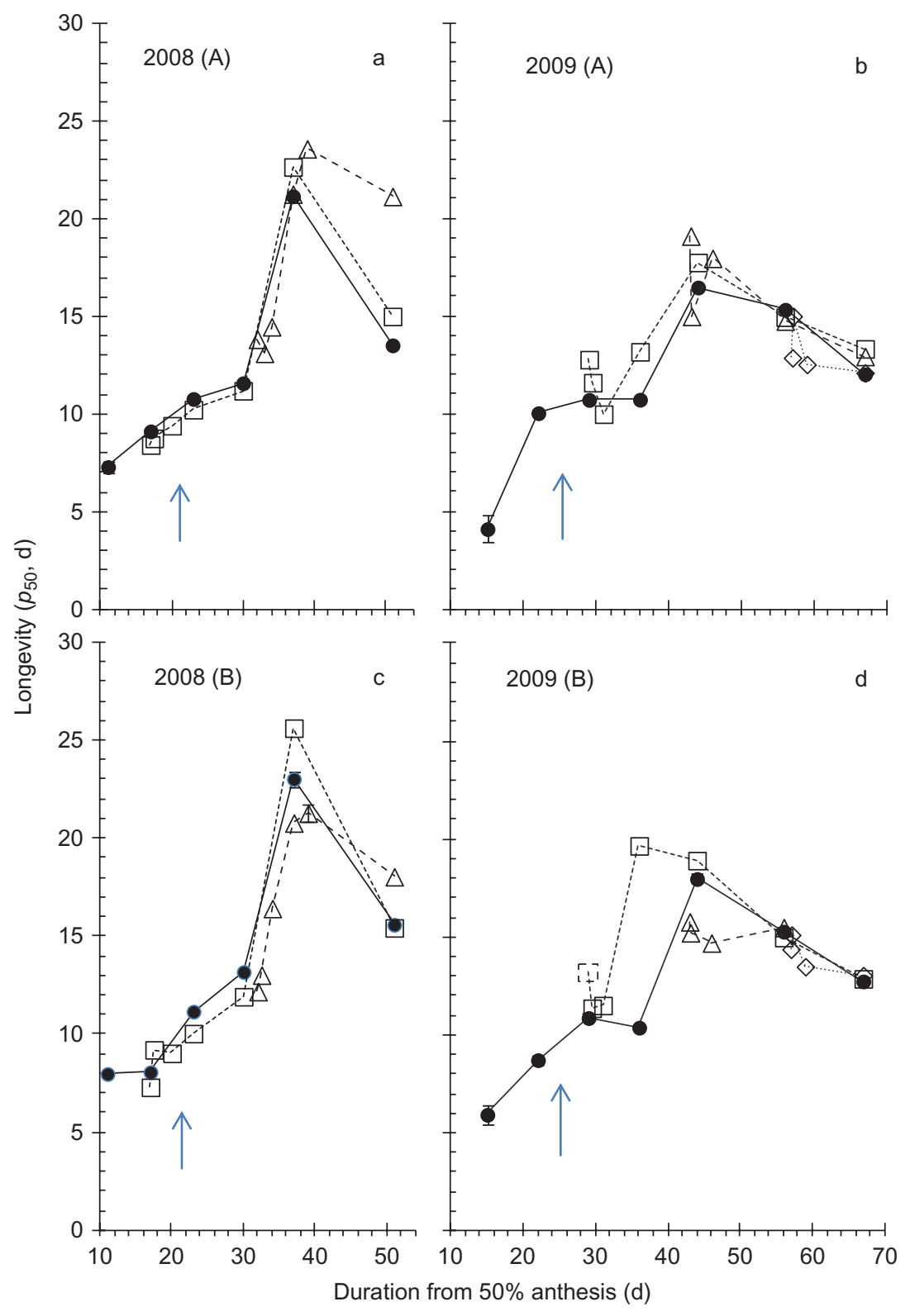

Figure 3. Effect of simulated rainfall ( $30 \mathrm{~mm}$ applied above the canopy) on the subsequent air-dry seed storage longevity ( $p_{50}$, period of experimental hermetic storage at $40^{\circ} \mathrm{C}$ with $c .15 \%$ moisture content until viability reduced to $50 \%$, estimates provided by probit analysis, Table 1) of wheat seeds harvested serially during their development and maturation from field-grown crops in Blocks A (a, b) and B (c, d) in 2008 (a, c) or 2009 (b, d) for the control (-•-, no simulated additional rainfall), wetting 1 ( ... $\square . .$. and wetting $2(--\triangle--)$ in 2008 , or also with wetting $3(\diamond)$ in 2009 . Vertical bars show standard errors of the estimates of $p_{50}$ where larger than symbols. Arrows indicate mass maturity.

Immediate, small reductions in longevity resulted from wetting in these circumstances (essentially a 2- to 4 -d perturbation which delayed the pattern of seed quality improvement), but there was no evidence of reduced longevity relative to the control in the later samples harvested after 37 DAA (Fig. 3a, c). Simulated rainfall was applied later in development in 2009, and the second and third treatments, at about the point of peak longevity or $15 \mathrm{~d}$ later, showed evidence of slight damage to longevity after wetting but, similarly, close agreement with control estimates amongst later harvests (Fig. 3b, d). In the protected environment of 2010, wetting only at or after harvest maturity, there was a far greater and more repeatable pattern of an immediate reduction in longevity after wetting with subsequent improvement towards estimates similar to the control (Fig. 4). Moreover, comparison with the third wetting treatment in 2009, the only field treatment applied close to harvest maturity, shows good agreement with the 2010 pattern. Provided that 


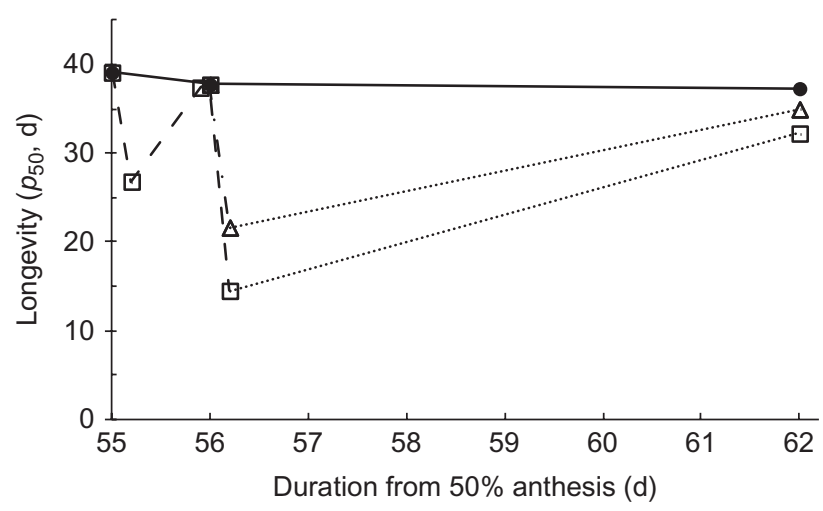

Figure 4. Effect of simulated rainfall ( $25 \mathrm{~mm}$ applied above the canopy) on the subsequent air-dry seed storage longevity ( $p_{50}$, period of experimental hermetic storage at $40^{\circ} \mathrm{C}$ with $c$. $15 \%$ moisture content until viability reduced to $50 \%$, estimates provided by probit analysis, Table 1) of wheat seeds harvested serially at or after harvest maturity produced protected from rainfall in a polythene tunnel house in 2010 for control (--, no simulated rainfall), wetting once at 56 DAA $\left(-\triangle^{-}\right)$or on two consecutive days (- ---$)$at 55 and 56 DAA. The dotted lines joining symbols between 56 and 62 DAA may not represent the real pattern. Vertical bars show standard errors of the estimates of $p_{50}$ where larger than symbols.

germination does not occur, we suggest that the reversible effect detected here in wheat could occur in other plant species with seeds that undergo maturation drying with little protection from rainfall.

Oligosaccharides (e.g. Crowe et al., 1984; Leopold, 1990) and low molecular weight heat-stable proteins (e.g. Galau et al., 1986) have been posited to play significant roles in seed survival in the air-dry state. Both have been associated with improvements to subsequent seed longevity during seed development and maturation, but with oligosaccharides accumulating more during development and heat-stable proteins more during maturation drying (Sinniah et al., 1998). Similarly, therefore, we would caution against the simple notion that the cause(s) of the immediate reduction to subsequent longevity and later reversal of damage is the same during the seed-filling phase as during maturation drying and/or at harvest maturity. In the latter case, the decline in longevity within a few hours of wetting and rapid subsequent recovery, in only $1 \mathrm{~d}$, apparent at 55-56 DAA in 2010 (Fig. 4) at comparatively low moisture contents (Fig. 2), would seem to militate against, for example, complex carbohydrate chemistry or considerable protein synthesis (as occur substantially earlier in development). Wetting-drying cycles affect the degree of hysteresis of seed moisture content-equilibrium relative humidity isotherms in mature wheat seeds (Pixton and Warburton, 1973). The formation of intracellular glasses is one of the factors reported to be indispensable to air-dry seed survival (Buitink and
Leprince, 2004). Cells compress during desiccation, with glass formation providing protection from such damage, and Walters (2015) has suggested that the resultant newly formed intra-molecular spatial arrangements affect seed survival. Such hypotheses may be relevant to the effects detected here at harvest maturity. Hence, the experimental approaches developed here might be of utility to those investigating the fundamental basis of seed survival in the air-dry state.

Research by Woodward (1990) and Piggot and Huntley (1981), for example, has provided clear evidence of the importance of patterns of temperature at critical stages in seed formation and development to the geographic distribution of plant species. Similarly, rainfall patterns affect plant distribution greatly (Woodward, 1996). The effects shown here in wheat cv. Tybalt may have possible parallels in wild species. For example, in Galanthus nivalis and Narcissus pseudonarcissus, hydration in the summer period after shedding in late spring enabled further seed development and maturation, which affected subsequent patterns of loss in dormancy in response to seasonal patterns of temperature (Newton et al., 2013, 2015). Hence, if they occur in other species, then at a minimum such effects of rainfall on longevity may affect subsequent gap finding and competitive ability in seed-seedling cycles - by affecting not the amount but the quality of seeds produced - and potentially the geographic distribution of a species if such effects occur at the edges of their ranges, and potentially in response to climate change.

We caution that the novel effects reported here are for a single cultivar of one (crop) plant species. Within that limitation, we conclude that rainfall causing ear wetting in planta late in maturation drying, insufficient to result in pre-harvest sprouting, may nonetheless reduce subsequent ex planta air-dry seed longevity immediately, but that in such circumstances the damage can be reversed by delaying harvest to enable a period of re-drying in planta. In terms of seed production practices, this supports the traditional UK approach of delaying wheat seed harvest in wet conditions until the crop re-dries. The evidence that wetting during seed filling may also damage longevity is less clear but, in this case also, damage was reversed with further development in planta. Hence, we are not able to conclude whether damage from rainfall to subsequent seed longevity is subject to interaction with stage of seed development.

\section{Acknowledgements}

We thank Caroline Hadley, Richard Casebow, Laurence Hansen and Dr Tran Dang-Hong for their considerable help with this study. 


\section{Financial support}

The Commonwealth Scholarship Commission provided a research studentship to G.Y.

\section{Conflicts of interest}

None.

\section{References}

Argerich, C.A., Bradford, K.J. and Tarquis, A.M. (1989) The effects of priming and aging on resistance to deterioration of tomato seeds. Journal of Experimental Botany 40, 593-598.

Buitink, J. and Leprince, O. (2004) Glass formation in plant anhydrobiotes: survival in the dry state. Cryobiology 48, 215-228.

Butler, L.H., Hay, F.R., Ellis, R.H., Smith, R.D. and Murray, T.B. (2009) Priming and re-drying improve the survival of mature seeds of Digitalis purpurea during storage. Annals of Botany 103, 1261-1270.

Crowe, J.H., Crowe, L.M. and Chapman, D. (1984) Preservation of membranes in anhydrobiotic organisms: the role of trehalose. Science 223, 701-703.

Ellis, R.H. and Pieta-Filho, C. (1992) The development of seed quality in spring and winter cultivars of barley and wheat. Seed Science Research 2, 9-15.

Ellis, R.H. and Roberts, E.H. (1980) Improved equations for the prediction of seed longevity. Annals of Botany 45, $13-30$.

Ellis, R.H., Hong, T.D. and Jackson, M.T. (1993) Seed production environment, time of harvest and the potential longevity of seeds of three cultivars of rice (Oryza sativa L.). Annals of Botany 72, 583-590.

Galau, G.A., Hughes, D.W. and Dure, L. III. (1986) Abscisic acid induction of cloned late embryogenesis-abundant (Lea) mRNAs. Plant Molecular Biology 7, 155-170.

Gooding, M.J., Ellis, R.H., Shewry, P.R. and Schofield, J.D. (2003) Effects of restricted water availability and increased temperature on the grain filling, drying and quality of winter wheat. Journal of Cereal Science 37, 295-309.

Gualano, N.A., Del Fueyo, P.A. and Benech-Arnold, R.L. (2014) Potential longevity $\left(K_{\mathrm{i}}\right)$ of malting barley (Hordeum vulgare L.) grain lots relates to their degree of pregermination assessed through different industrial quality parameters. Journal of Cereal Science 60, 222-228.

Hong, T.D. and Ellis, R.H. (1992) The survival of germinating orthodox seeds after desiccation and hermetic storage. Journal of Experimental Botany 43, 239-247.

Intergovernmental Panel on Climate Change (2014) Climate Change 2014: Synthesis Report. Contribution of Working Groups I, II and III to the Fifth Assessment Report of the Intergovernmental Panel on Climate Change [Core Writing Team, R.K. Pachauri and L.A. Meyer (Eds)]. Geneva, The Intergovernmental Panel on Climate Change.

International Seed Testing Association (2011) International rules for seed testing. Edition 2011. Switzerland, The International Seed Testing Association.
Kettlewell, P.S., Stephenson, D.B., Atkinson, M.D. and Hollins, P.D. (2003) Summer rainfall and wheat grain quality: relationships with the North Atlantic Oscillation. Weather 58, 155-164.

King, R.W. (1993) Manipulation of grain dormancy in wheat. Journal of Experimental Botany 44, 1059-1066.

Landau, S., Mitchell, R.A.C., Barnett, V., Colls, J.J., Craigon, J. and Payne, R.W. (2000) A parsimonious, multiple-regression model of wheat yield response to environment. Agricultural and Forest Meteorology 101, 151-166.

Leopold, A.C. (1990) Coping with desiccation. pp. 57-86 in Alscher, R.G.; Cumming, J.R. (Eds) Stress responses in plants: adaptation and acclimation mechanisms. New York, Wiley-Liss.

MacKay, D.B. (1972) The measurement of viability. pp. 172-208 in Roberts, E.H. (Ed.) Viability of seeds. London, Chapman \& Hall.

Mitchell, B., Armstrong, C., Black, M. and Chapman, J. (1980) Physiological aspects of sprouting and spoilage in developing Triticum aestivum L. (wheat) grains. pp. 339-356 in Hebblethwaite, P.D. (Ed.) Seed production. London, Butterworths.

Newton, R.J., Hay, F.R. and Ellis, R.H. (2013) Seed development and maturation in early spring-flowering Galanthus nivalis and Narcissus pseudonarcissus continues post-shedding with little evidence of maturation in planta. Annals of Botany 111, 945-955.

Newton, R.J., Hay, F.R. and Ellis, R.H. (2015) Ecophysiology of seed dormancy and the control of germination in early spring-flowering Galanthus nivalis and Narcissus pseudonarcissus (Amaryllidaceae). Botanical Journal of the Linnean Society 177, 246-262.

Olivares, A., Johnston, M. and Calderon, C. (2009) Effect of rainfall regimes on seed production and quality of Avena barbata. Ciencia e Investigacion Agraria 36, 69-76.

Pieta-Filho, C. and Ellis, R.H. (1991) The development of seed quality in spring barley in four environments. I. Germination and longevity. Seed Science Research 1, $163-177$.

Pigott, C.D. and Huntley, J.P. (1981) Factors controlling the distribution of Tillia cordata at the northern limits of its geographical range III. Nature and causes of seed sterility. New Phytologist 87, 817-839.

Pixton, S.W. and Warburton, S. (1973) The influence of the method used for moisture adjustment on the equilibrium relative humidity of stored products. Journal of Stored Products Research 9, 189-197.

Rao, N.K., Appa Rao, S., Mengesha, M.H. and Ellis, R.H. (1991) Longevity of pearl millet (Pennisetum glaucum) seeds harvested at different stages of maturity. Annals of Applied Biology 119, 97-103.

Sanhewe, A.J., Ellis, R.H., Hong, T.D., Wheeler, T.R., Batts, G.R., Hadley, P. and Morison, J. (1996) The effect of temperature and $\mathrm{CO}_{2}$ on seed quality development in wheat (Triticum aestivum L.). Journal of Experimental Botany 47, 631-637.

Sinniah, U.R., Ellis, R.H. and John, P. (1998) Irrigation and seed quality development in rapid-cycling Brassica: soluble carbohydrates and heat-stable proteins. Annals of Botany 82, 647-655.

Sivakumar, M., Das, H. and Brunini, O. (2005) Impacts of present and future climate variability and change on agriculture and forestry in the arid and semi-arid tropics. Climatic Change 70, 31-72. 
Smith, G.P. and Gooding, M.J. (1999) Models of wheat grain quality considering climate, cultivar and nitrogen effects. Agricultural and Forest Meteorology 94, 159-170.

Tarquis, A.M. and Bradford, K.J. (1992) Prehydration and priming treatments that advance germination also increase the rate of deterioration of lettuce seeds. Journal of Experimental Botany 43, 307-317.

Thomason, W.E., Hughes, K.R., Parrish, D.J. and Barbeau, W.E. (2009) Understanding pre-harvest sprouting of wheat. Publication 424-060, pp. 1-4. Virginia, Virginia State University.

Thomson, D.J. (1979) Production and the prediction of growth. Proceedings of the Nutrition Society 38, 303-308.

Tu, J.C., McDonnell, M. and Dirks, V.A. (1988) Factors affecting seed quality of navy bean in the field in
South Western Ontario. Seed Science and Technology 16, 371-381.

Villiers, T.A. and Edgecumbe, D.J. (1975) On the cause of seed deterioration in dry storage. Seed Science and Technology 3, 61-74.

Walters, C. (2015) Orthodoxy, recalcitrance and in-between: describing variation in seed storage characteristics using threshold responses to water loss. Planta 242, 397-406.

Woodward, F.I. (1990) The impact of low temperatures in controlling the geographical distribution of plants. Philosophical Transactions of the Royal Society of London Series B 326, 585-593.

Woodward, F.I. (1996) Climate and plant distribution. Cambridge, UK, Cambridge University Press. 